Article

\title{
Enzymatic Production of Biodiesel Using Immobilized Lipase on Core-Shell Structured $\mathrm{Fe}_{3} \mathrm{O}_{4} @ \mathrm{MIL}-100(\mathrm{Fe})$ Composites
}

\author{
Wenlei Xie * and Mengyun Huang \\ School of Chemistry and Chemical Engineering, Henan University of Technology, Zhengzhou 450001, China; \\ huangmengyun1@gmail.com \\ * Correspondence: xwenlei@haut.edu.cn; Tel.: +86-371-6775-6302; Fax: +86-371-6775-6718
}

Received: 10 September 2019; Accepted: 9 October 2019; Published: 12 October 2019

check for updates

\begin{abstract}
In this research, core-shell structured $\mathrm{Fe}_{3} \mathrm{O}_{4} @ \mathrm{MIL}-100(\mathrm{Fe})$ composites were prepared by coating $\mathrm{Fe}_{3} \mathrm{O}_{4}$ magnetite with porous MIL-100(Fe) metal-organic framework (MOF) material, which were then utilized as magnetic supports for the covalent immobilization of the lipase from Candida rugosa through amide linkages. By using the carbodiimide/hydroxysulfosuccinimide (EDC/NHS) activation strategy, the lipase immobilization efficiency could reach $83.1 \%$, with an activity recovery of $63.5 \%$. The magnetic $\mathrm{Fe}_{3} \mathrm{O}_{4} @ \mathrm{MIL}-100(\mathrm{Fe})$ composite and immobilized lipase were characterized by several techniques. The characterization results showed that the $\mathrm{Fe}_{3} \mathrm{O}_{4}$ core was coated with MIL-100(Fe) shell with the formation of perfect core-shell structured composites, and moreover, the lipase was covalently tethered on the magnetic carrier. The immobilized lipase displayed a strong magnetic response and could be facilely separated by an external magnetic field. With this magnetic biocatalyst, the maximum biodiesel conversion attained $92.3 \%$ at a methanol/oil molar ratio of 4:1, with a three-step methanol addition manner, and a reaction temperature of $40^{\circ} \mathrm{C}$. Moreover, the biocatalyst prepared in the present study was recycled easily by magnetic separation without significant mass loss, and displayed $83.6 \%$ of its initial activity as it was reused for five runs, thus allowing its potential application for the cleaner production of biodiesel.
\end{abstract}

Keywords: magnetic composite; immobilized lipase; transesterification; biodiesel; metal-organic framework

\section{Introduction}

Biodiesel fuels, basically consisting of methyl esters of long-chain fatty acids (FAs) and as a viable alternative clean energy, are expected to replace petroleum-based fuels in accordance with the requirements of sustainable development [1,2]. Commonly, biodiesel is easily produced by catalytic transesterification of plant oils or animal fats with methanol. Conventional homogeneous alkaline catalysts (including $\mathrm{NaOH}$ or $\mathrm{KOH}$ ) are frequently adopted for the transesterification reaction thanks to their high activities. However, the homogeneously catalyzed transesterification process has major constraints for the production of biodiesel, such as the difficulties in the catalyst recovery and the undesirable yielded wastewater $[3,4]$. In this connection, a green and cleaner production has stimulated development of heterogeneous catalysts as replacements for homogeneous catalysts for the transesterification processes. Heterogeneous catalysts have several merits in addressing the aforementioned issues of homogeneous catalysts, such as they are environmental friendly, have easy separation, and have fewer disposal problems, thus greatly minimizing the formation of wastes and allowing the transesterification procedure to be even more effective $[5,6]$.

Lipases (triacylglycerol hydrolases, EC 3.1.1.3) are an important class of enzymes, which are used widely for esterification and transesterification reactions. The lipase-mediated transesterification 
process is environmentally friendly, sustainable, and has a lower susceptibility to free FAs and moisture present in the oil feedstocks, and thus is beneficial for biodiesel production [7]. In comparison with chemical catalysts, the production of biodiesel using lipase catalysts can provide several advantages, such as mild reaction conditions, non-toxicity, and less by-products [8,9]. However, the practical application of native lipases suffers from inherent hitches, including their difficulties of recovery and their unsatisfactory operational stabilities. The immobilization of lipase on suitable porous carriers is an efficient approach to improve the enzymatic biodiesel production by enhancing the catalytic stability and facilitating the reutilization of lipase $[9,10]$. In this regard, various methods for lipase immobilization, including physical adsorption, covalent binding, as well as hydrophobic ion affinity ligation, have been extensively explored so far. In particular, covalent binding approach is deemed to be a viable and appealing method for the immobilization of a lipase by the tight fixation of the enzyme against its leaching from the support [11-13].

Over the past decades, a growing attention has been paid to porous nanomaterials that can be employed as an important support for enzyme immobilization because of their large surface area and low mass transfer resistance [14]. The reduction in the size of the immobilized lipase can permit better exposure to and access of the active sites. Filtration and centrifugation methods are usually utilized for the separation of the immobilized lipase from the reaction mixture. In most cases, the recycling of immobilized lipases with small sizes is difficult, making these conventional separation methods time-consuming and inefficient. Moreover, the inevitable loss of the biocatalysts in the separation processes can also preclude their wide practical application [12,14]. From a sustainability point of view, it is still of great demand to fabricate a novel enzyme support with the aim of improving the separation performance of the immobilized lipase. Quite recently, magnetic materials, when used as enzyme supports, have attracted great research attention since the magnetite-loaded enzyme can allow solid-liquid separation to be done fast and facilely, with minimal mass loss, by applying an external magnet $[15,16]$. Unfortunately, magnetic nanoparticles may easily aggregate into large clusters, owing to their magnetic dipole-dipole attractions. This phenomenon greatly lowers the catalytic activities and impedes them from being well-dispersed in the liquid substrate mixture. Additionally, the naked magnetic nanoparticles always show instability over longer periods of time because of their sensitivities to oxidation $[17,18]$. To address these issues, appropriate passive porous materials, such as carbon materials, silica, and organic polymer, are reported to be coated on the magnetic nanoparticles in an attempt to greatly suppress their aggregation and also to effectively enhance their chemical stabilities $[19,20]$. The thus-formed core-shell structured composites, consisting of a magnetite core and a porous material shell, are of particular interest due to the comprehensive advantages of their individual components.

Among the porous materials, metal-organic frameworks (MOFs), produced through self-assembly of metal clusters with interconnected organic linkers, have become regarded as excellent catalyst supports owing to their highly ordered crystalline structure, tunable porosity, and large surface area [21]. However, to our knowledge, very limited works have appeared to immobilize the lipase on the MOF support [22,23]. Nevertheless, the encapsulation of MOF materials onto the magnetic nanoparticle is attempted in order to fabricate core-shell magnetic composites that can combine a high regular porosity with a magnetic property. The so-formed hybrid composites would be beneficial for high lipase loading and strong affinity for lipase, and more significantly, can be facilely separated and reutilized by an external magnetic field.

The iron(III) trimesate MIL-100(Fe) MOF (MIL = Materials of Institute Lavoisier) materials are made up of trimers of iron(III) octahedra interconnected via covalent bonds to the 1,3,5-benzenetricarboxylate linker, possessing a rigid zeotype crystal structure with high surface area, abundant carboxyl groups, and high chemical stabilities [24-26]. Of particular interest, these surface carboxyl groups are exposed on the surface of MIL-100(Fe) MOFs and can be activated by the carbodiimide/hydroxysulfosuccinimide (EDC/NHS) strategy [27]. Subsequently, the so-activated MIL-100(Fe) MOFs are covalently bound to 
the lipase by amide linkages to afford the immobilized lipase, whereby the lipase is highly accessible and retains good activities.

Based on the above considerations, the present research was intended to prepare core-shell structured $\mathrm{Fe}_{3} \mathrm{O}_{4} @$ MIL-100(Fe) composites by a step-by-step self-assembly methodology, and then the lipase from Candida rugosa was bound onto the surface of the core-shell magnetic composites using EDC/NHS activation strategy so as to form a magnetically recyclable biocatalyst. The $\mathrm{Fe}_{3} \mathrm{O}_{4} @ \mathrm{MIL}-100(\mathrm{Fe})$ composite and immobilized lipase were fully characterized by means of enzymatic activity assays, Fourier transform infrared (FT-IR) spectra, transmission electron microscopy (TEM), vibrating-sample magnetometer (VSM), powder X-ray diffraction (XRD), X-ray photoelectron spectroscopy (XPS), and nitrogen adsorption-desorption measurements. The lipase immobilization process was optimized regarding the immobilization efficiency and activity recovery. The catalytic activity was investigated in the transesterification of soybean oil for the enzymatic production of biodiesel. Here, soybean oil was selected as a feedstock mainly due to its easy availability in China.

The main innovation of this research is related to the preparation of the recyclable biocatalyst with a magnetic core-shell structure and its successful application for the cleaner production of biodiesel in a heterogeneous manner. Particularly, this magnetic behavior permits the developed biocatalyst to be easily and efficiently recycled, with minimal mass loss, by using a permanent magnet.

\section{Results and Discussion}

\subsection{Enzymatic Activities of the Immobilized Lipase}

The synthetic route of the $\mathrm{Fe}_{3} \mathrm{O}_{4} @ \mathrm{MIL}-100(\mathrm{Fe})$ support and immobilized lipase is depicted in Figure 1. EDTA-2Na was used for the functionalization of magnetic particles, and the carboxyl-functionalized $\mathrm{Fe}_{3} \mathrm{O}_{4}$ particles are coated with MIL-100(Fe) MOFs by means of a step-by-step self-assembly method. In this case, the chelation interactions between $\mathrm{Fe}^{2+}$ cations on the $\mathrm{Fe}_{3} \mathrm{O}_{4}$ particles and the bridging organic linkers $\left(\mathrm{COO}^{-}\right)$of $\mathrm{MIL}-100(\mathrm{Fe}) \mathrm{MOFs}$ can induce the initial nucleation and growth of the MOF shell. Moreover, this layer-by-layer approach can endow the uniform deposition of the MIL-100(Fe) shell, and the MOF thickness on the magnetic particles can also be modulated by performing different growth cycles. The uniform thickness of the MIL-100(Fe) MOFs is favorable for high loadings of lipase on the magnetic composite. Thereafter, the resultant $\mathrm{Fe}_{3} \mathrm{O}_{4} @ M I L-100(\mathrm{Fe})$ was chemically activated by the EDC/NHS strategy to generate imide functionalities on the magnetic support surface for the subsequent covalent binding with amino groups of the lipase. By this EDC/NHS activation strategy, the lipase could be firmly fixed on the surface of the core-shell magnetic support, on which several terminal amino groups of the lipase react readily with the NHS ester groups. As the lipase is bound to the magnetic support, its structure seems to become more rigid, thereby leading to the improved stabilities of the bound lipase.

The enzymatic activity of the immobilized lipase was assessed in the transesterification of soybean oil. As expected, the transesterification reaction did not take place without a catalyst, and the $\mathrm{Fe}_{3} \mathrm{O}_{4} @$ MIL-100(Fe) support exhibited no catalytic activity for the transesterification reaction. As the native lipase was used for the reaction, the oil conversion of $91.8 \%$ could be obtained under the reaction conditions. However, as aforementioned, the native lipase has technical problems due to its homogeneous nature, including the difficulty of the separation together with non-reusability of biocatalysts. In order to examine the possibility of the physical adsorption of lipase on the magnetic support, we attempted to prepare the immobilized lipase without the EDC/NHS activation step. The thus-obtained biocatalyst showed lower activities toward the transesterification reaction, giving an oil conversion of $65.6 \%$. Moreover, the oil conversion was remarkably reduced to $35.8 \%$ as the recovered biocatalyst was utilized for the first recycle run. However, after immobilization of lipase onto the magnetic support with the EDC/NHS activation methodology, the immobilized lipase developed in the present research displayed high transesterification activities and stabilities with an oil conversion of $92.3 \%$. 


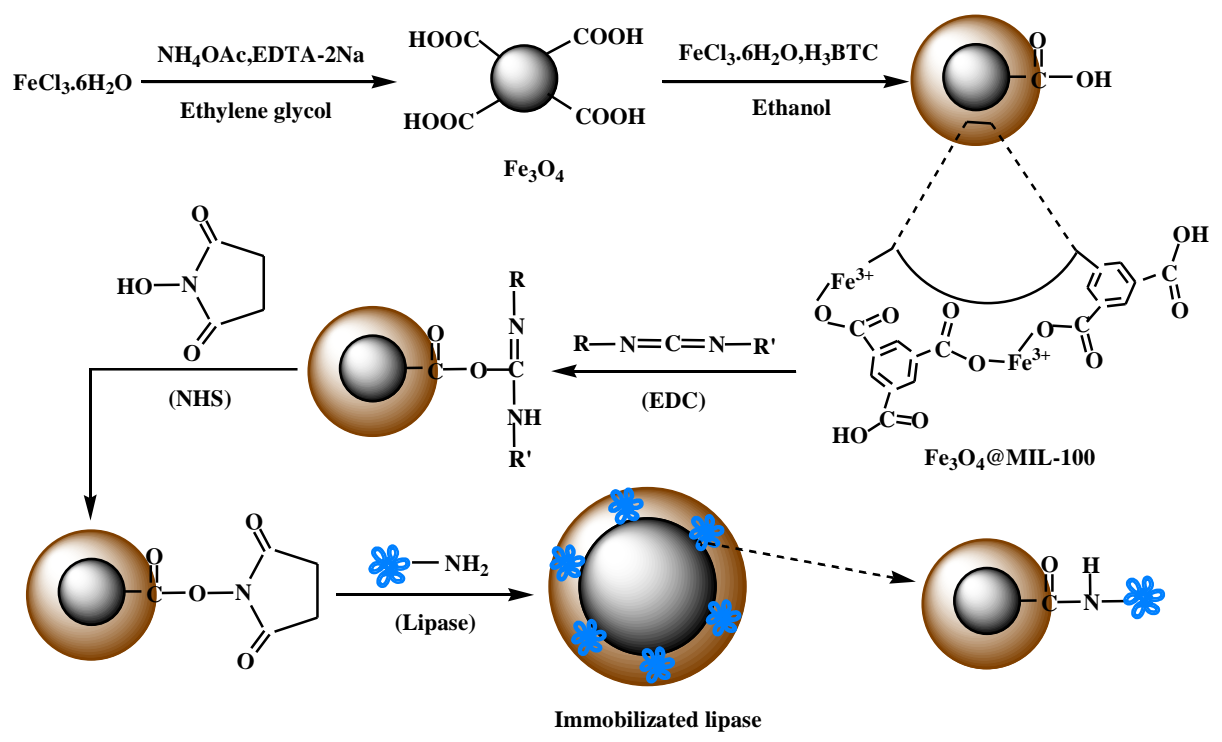

Figure 1. Schematic representation of the preparation of core-shell structured $\mathrm{Fe}_{3} \mathrm{O}_{4} @ \mathrm{MIL}-100(\mathrm{Fe})$ composites and the subsequent immobilization of lipase onto the magnetic composite.

\subsection{Characteristics of the Immobilized Lipase}

Figure 2 presents the graphical FT-IR spectra of the magnetite core, naked $\mathrm{Fe}_{3} \mathrm{O}_{4} @ \mathrm{MIL}-100(\mathrm{Fe})$, and lipase-bound $\mathrm{Fe}_{3} \mathrm{O}_{4} @ M I L-100(\mathrm{Fe})$. For $\mathrm{Fe}_{3} \mathrm{O}_{4}$ sample (Figure 2a), the IR absorption peak at $586 \mathrm{~cm}^{-1}$ was discernible, which could be assigned to the characteristic absorption of $\mathrm{Fe}-\mathrm{O}$ bond in the $\mathrm{Fe}_{3} \mathrm{O}_{4}$ magnetite [16,18]. In addition, the IR band at $1635 \mathrm{~cm}^{-1}$ mainly originated from the bending vibration of water present in the magnetite [16]. Moreover, the shoulder IR peak at $1709 \mathrm{~cm}^{-1}$ resulted from the $\mathrm{C}=\mathrm{O}$ stretching vibration of the surface carboxyl groups, which elaborated that the surface of the $\mathrm{Fe}_{3} \mathrm{O}_{4}$ was carboxyl-functionalized for the subsequent coating with the MIL-100(Fe) MOFs. As for the $\mathrm{Fe}_{3} \mathrm{O}_{4} @ M I L-100(\mathrm{Fe})$ sample (Figure 2b), the IR absorption band situated at $1713 \mathrm{~cm}^{-1}$ was reasonably attributed to the $\mathrm{C}=\mathrm{O}$ stretching mode in the MIL-100(Fe) component. Moreover, two distinct IR peaks appeared at $1629 \mathrm{~cm}^{-1}$ and $1376 \mathrm{~cm}^{-1}$, which could correspond to the $\mathrm{COO}^{-}$anti-symmetric and symmetric stretching vibration of the organic ligand $\mathrm{H}_{3} \mathrm{BTC}$, respectively [24,25]. In additional, the IR absorption peaks at $1571 \mathrm{~cm}^{-1}$ and $1441 \mathrm{~cm}^{-1}$ could be ascribed to the stretching vibration of benzene rings [28]. Obviously, the Fe-O bond vibration absorption peak was also shown at $586 \mathrm{~cm}^{-1}$, demonstrating that the existence of $\mathrm{Fe}_{3} \mathrm{O}_{4}$ in the magnetic $\mathrm{Fe}_{3} \mathrm{O}_{4} @ \mathrm{MIL}-100(\mathrm{Fe})$ support. In the IR spectrum of the immobilized lipase, there were two IR absorption bands at $1642 \mathrm{~cm}^{-1}$ and $1551 \mathrm{~cm}^{-1}$ to be observed as shown in Figure 2c. Even though these two IR bands were probably overlapped with the $\mathrm{COO}^{-}$anti-symmetric and symmetric stretching vibration absorption bands, they mainly originated from amide I and II of the lipase $[15,18]$. Furthermore, the characteristic IR bands assignable to the $\mathrm{Fe}_{3} \mathrm{O}_{4} @ \mathrm{MIL}-100(\mathrm{Fe})$ support were also found for the immobilized lipase. Such IR results collectively revealed that the amide linkages were formed between the enzyme and the magnetic composite during the immobilization process. Taking these IR results into account, we can conclude that the lipase was indeed bound on the $\mathrm{Fe}_{3} \mathrm{O}_{4} @ \mathrm{MIL}-100(\mathrm{Fe})$ support.

The morphological characteristics of the $\mathrm{Fe}_{3} \mathrm{O}_{4}, \mathrm{Fe}_{3} \mathrm{O}_{4} @ \mathrm{MIL}-100(\mathrm{Fe})$, and the immobilized lipase were identified by SEM and TEM techniques. As can be observed from the SEM images (Figure 3), the $\mathrm{Fe}_{3} \mathrm{O}_{4}$ particles had a regularly spherical shape with uniform particle size. Moreover, the $\mathrm{Fe}_{3} \mathrm{O}_{4} @ \mathrm{MIL}-100(\mathrm{Fe})$ and immobilized lipase also displayed spherical shapes, and the mean particle sizes for the two samples were increased after the coating of MIL-100(Fe) MOF and subsequent binding of the lipase. The TEM images of the selected samples are presented in Figure 4. Morphologically, the $\mathrm{Fe}_{3} \mathrm{O}_{4}$ microspheres were uniform and monodispersed with a mean diameter of about $300 \mathrm{~nm}$. After being encapsulated with MIL-100(Fe) MOF, the obtained $\mathrm{Fe}_{3} \mathrm{O}_{4} @ \mathrm{MIL}-100(\mathrm{Fe})$ composite showed 
a perfect core-shell structure, composed of a dark $\mathrm{Fe}_{3} \mathrm{O}_{4}$ core and a clear gray MOF shell, with a mean diameter of approximately $400 \mathrm{~nm}$, thus implying the magnetic core was virtually coated with the MIL-100(Fe) material. The thickness of the compact MOF shell can be adjusted by varying the growth cycles. In this work, after ten growth cycles, the MOF shell thickness of the $\mathrm{Fe}_{3} \mathrm{O}_{4} @ \mathrm{MIL}-100(\mathrm{Fe})$ composite was estimated to be approximately $100 \mathrm{~nm}$. Additionally, the morphology and size for the lipase-bound $\mathrm{Fe}_{3} \mathrm{O}_{4} @ \mathrm{MIL}-100(\mathrm{Fe})$ samples were not significantly varied in comparison with the $\mathrm{Fe}_{3} \mathrm{O}_{4} @ \mathrm{MIL}-100(\mathrm{Fe})$ support, suggesting the magnetic core-shell structure was not destroyed after the lipase loading. As such, this core-shell structured support does not only have composite magnetic behaviors, but also offers accessible surface carboxyl groups for binding of the Candida rugosa lipase.

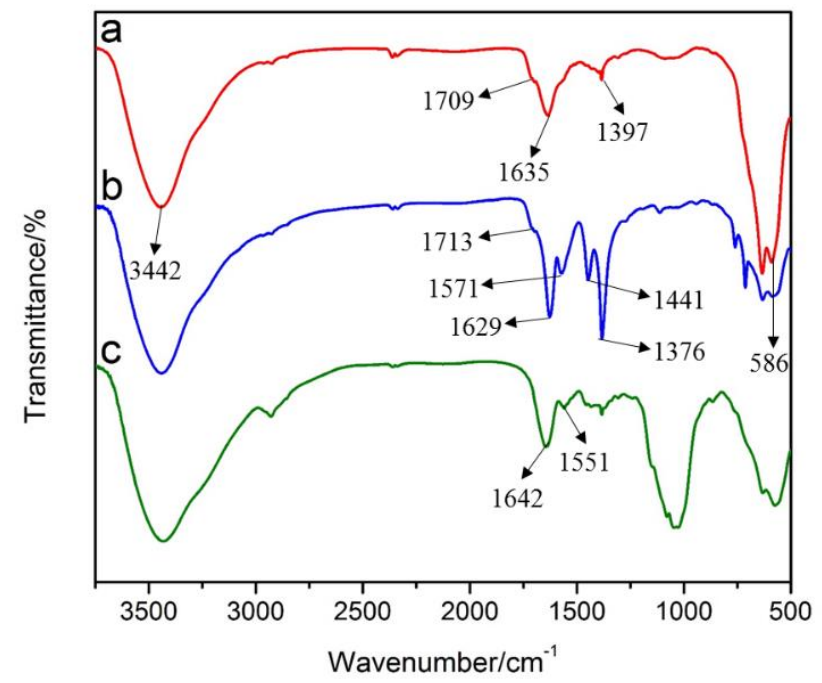

Figure 2. FT-IR spectra of $\mathrm{Fe}_{3} \mathrm{O}_{4}$ microsphere (a), $\mathrm{Fe}_{3} \mathrm{O}_{4} @ \mathrm{MIL}-100(\mathrm{Fe})$ support (b) and the immobilized lipase (c).

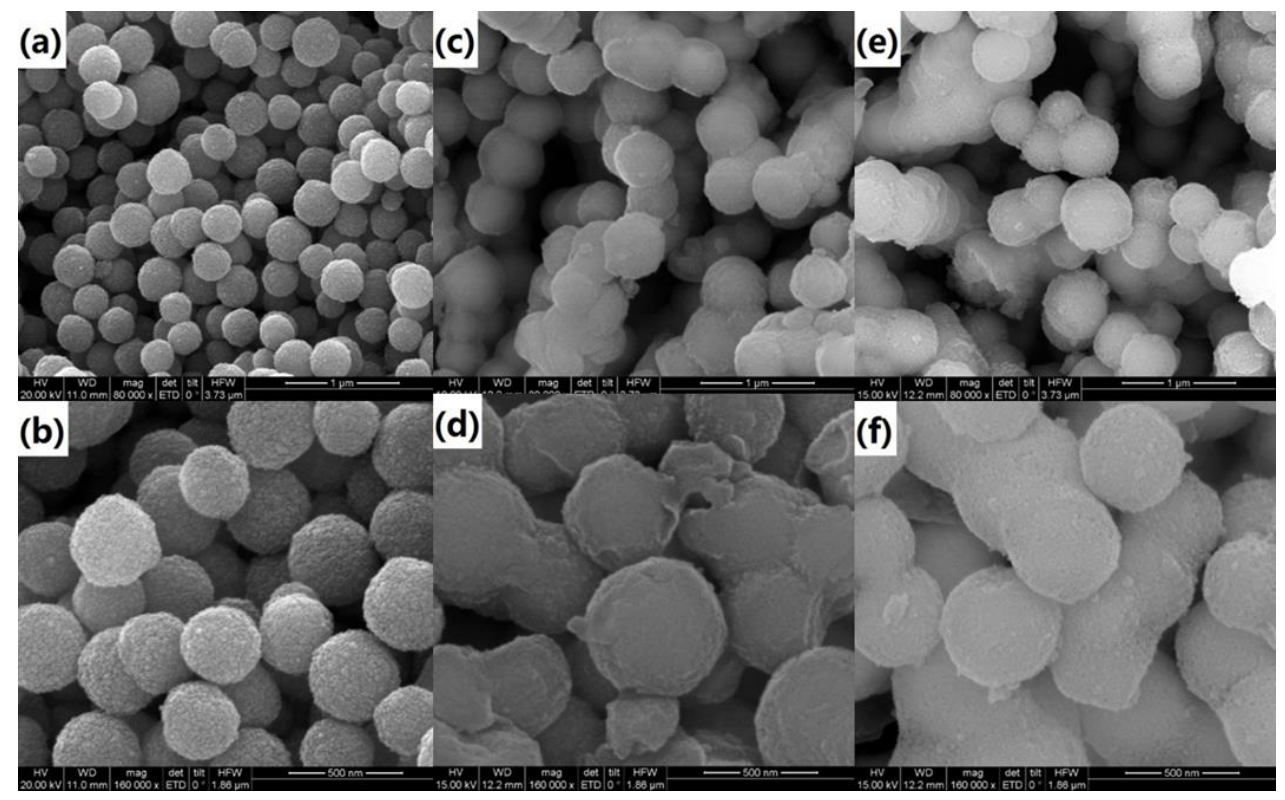

Figure 3. SEM images of $\mathrm{Fe}_{3} \mathrm{O}_{4}$ microsphere (a,b), $\mathrm{Fe}_{3} \mathrm{O}_{4} @ \mathrm{MIL}-100(\mathrm{Fe})$ support $(\mathbf{c}, \mathbf{d})$, and the immobilized lipase (e,f). 


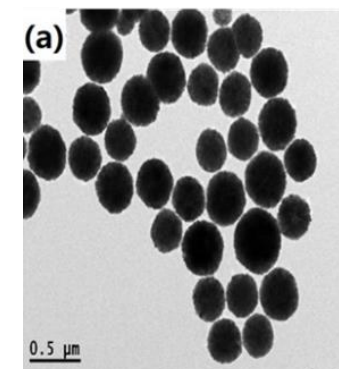

(b)

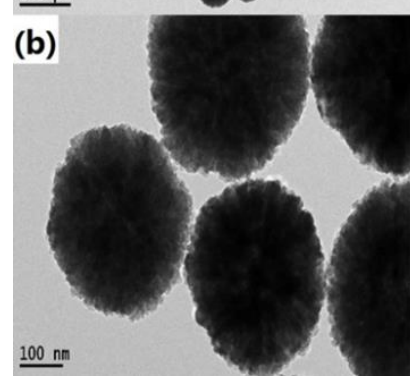

(c)
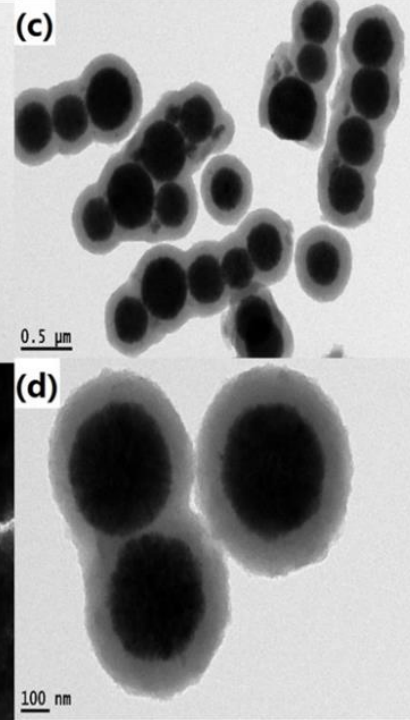

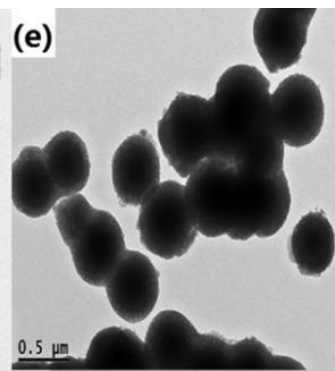

(f)

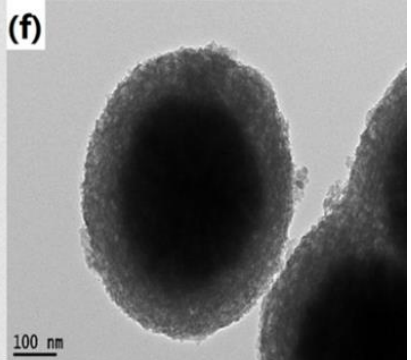

Figure 4. TEM images of $\mathrm{Fe}_{3} \mathrm{O}_{4}$ microsphere $(\mathbf{a}, \mathbf{b}), \mathrm{Fe}_{3} \mathrm{O}_{4} @ \mathrm{MIL}-100(\mathrm{Fe})$ support $(\mathbf{c}, \mathbf{d})$ and the immobilized lipase $(\mathbf{e}, \mathbf{f})$.

The crystalline structure of the $\mathrm{Fe}_{3} \mathrm{O}_{4}, \mathrm{Fe}_{3} \mathrm{O}_{4} @ \mathrm{MIL}-100(\mathrm{Fe})$, and the immobilized lipase was characterized by XRD techniques. As illustrated in Figure $5 \mathrm{a}$, the $\mathrm{Fe}_{3} \mathrm{O}_{4}$ showed six characteristic XRD peaks at $2 \theta$ of $30.1^{\circ}, 35.5^{\circ}, 43.2^{\circ}, 53.5^{\circ}, 57.2^{\circ}$, and $62.7^{\circ}$, which could be ascribed to the typical crystallographic plane reflections, (220), (311), (400), (422), (511), and (440), of $\mathrm{Fe}_{3} \mathrm{O}_{4}$ magnetite, respectively, corroborating a spinel crystalline structure of $\mathrm{Fe}_{3} \mathrm{O}_{4}$ (JCPDS database file, No.85-1436) $[16,18,29]$. After encapsulation of MIL-100(Fe) into $\mathrm{Fe}_{3} \mathrm{O}_{4}$, as disclosed in Figure $5 \mathrm{~b}$, the $\mathrm{Fe}_{3} \mathrm{O}_{4} @ M I L-100(\mathrm{Fe})$ support had similar characteristic XRD peaks to $\mathrm{Fe}_{3} \mathrm{O}_{4}$, with a slight difference in the Bragg diffraction intensity. Moreover, an additional XRD peak located at $10.9^{\circ}$ was observed, attributing to the crystallographic plane of the MIL-100(Fe) MOF [24,25]. Such XRD results further implied that the MIL-100(Fe) was practically coated onto the $\mathrm{Fe}_{3} \mathrm{O}_{4}$ magnetite and the crystal phase of the $\mathrm{Fe}_{3} \mathrm{O}_{4}$ remained essentially unchangeable in the preparation processes. After immobilization of the lipase, the characteristic XRD peaks for both $\mathrm{Fe}_{3} \mathrm{O}_{4}$ and MIL-100(Fe) were absolutely remained for the immobilized lipase (Figure 5c). Accordingly, the immobilized lipase well maintained its magnetic features, thus permitting the efficient and facile separation of the biocatalyst after the reaction.

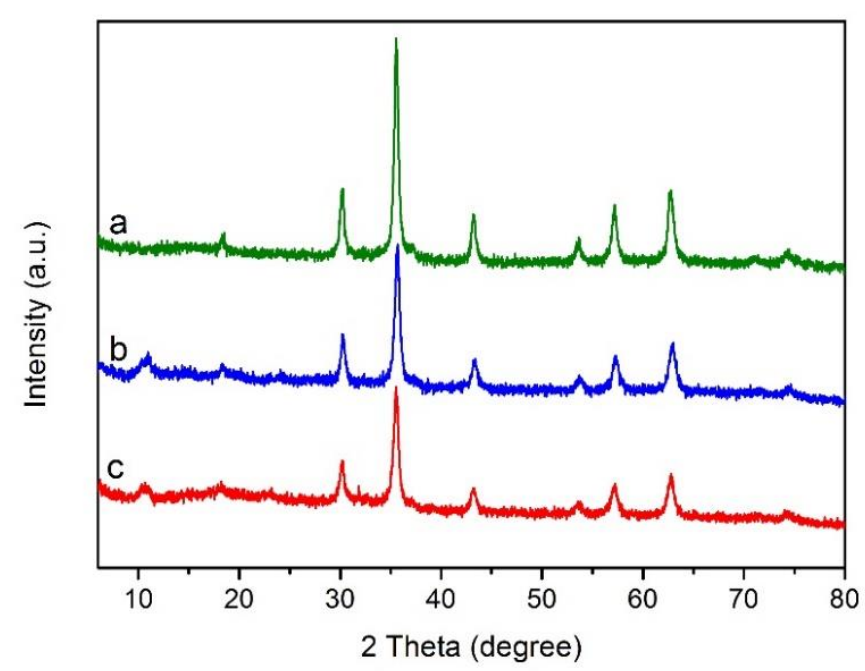

Figure 5. XRD patterns for $\mathrm{Fe}_{3} \mathrm{O}_{4}$ microsphere (a), $\mathrm{Fe}_{3} \mathrm{O}_{4} @ \mathrm{MIL}-100(\mathrm{Fe})$ support (b), and the immobilized lipase (c). 
To further verify the successful preparation of the magnetic support and the immobilized lipase, the surface chemical states were investigated by XPS techniques, as shown in Figure 6 . The comparative survey spectra (Figure 6a) exhibited various XPS peaks at binding energies of $286.35 \mathrm{eV}, 533.02 \mathrm{eV}$, and $712.01 \mathrm{eV}$, which could be attributable to $\mathrm{C} 1 \mathrm{~s}, \mathrm{O} 1 \mathrm{~s}$, and Fe $2 \mathrm{p}$ for both the magnetic support and the immobilized lipase, respectively $[25,30]$. More importantly, an extra N 1s XPS peak at a binding energy of $400.36 \mathrm{eV}$, due to the lipase, was clearly observed in Figure 6a for the immobilized lipase, further confirming that the lipase was practically tethered onto the magnetic composite. By using a curve-fitting approach, the deconvoluted $\mathrm{C} 1 \mathrm{~s}$ spectra of $\mathrm{Fe}_{3} \mathrm{O}_{4} @ \mathrm{MIL}-100(\mathrm{Fe})$ are illustrated in Figure $6 \mathrm{~b}$. As observed, three XPS peaks centered at $284.79 \mathrm{eV}, 286.27 \mathrm{eV}$, and $288.76 \mathrm{eV}$ were presented, which were tentatively assigned to $\mathrm{C}-\mathrm{C} / \mathrm{C}=\mathrm{C}$ (aromatic rings), $\mathrm{C}-\mathrm{O}$, and $\mathrm{O}-\mathrm{C}=\mathrm{O}$ of MIL-100(Fe), respectively [25]. In addition to the three similar XPS peaks, the curve-fitting $C$ 1s spectra of the immobilized lipase (Figure 6c) showed a new XPS peak situated at $285.42 \mathrm{eV}$, which was undoubtedly arisen from the $\mathrm{C}-\mathrm{N}$ of the lipase [31]. The high-resolution Fe 2p spectra of the $\mathrm{Fe}_{3} \mathrm{O}_{4} @ \mathrm{MIL}-100(\mathrm{Fe})$ and immobilized lipase are depicted in Figure 6d. For the two samples, the Fe 2p1/2 and Fe 2p3/2 peaks were observed at $725.43 \mathrm{eV}$ and $711.27 \mathrm{eV}$, respectively, with the separation (2p1/2-2p3/2) of $14.16 \mathrm{eV}$ highlighting the existence of $\mathrm{Fe}_{3} \mathrm{O}_{4}$ in the $\mathrm{Fe}_{3} \mathrm{O}_{4} @ M I L-100(\mathrm{Fe})$ and the immobilized lipase. Moreover, the satellite XPS peak at about $717.5 \mathrm{eV}$ was also seen for the two samples, which could be originated from the $\mathrm{Fe}(\mathrm{III})$ in the MIL-100(Fe) MOF [30]. Furthermore, the curve-fitting O 1s spectra of the immobilized lipase (Figure 6e) exhibited three XPS peaks at $530.55 \mathrm{eV}, 532.08 \mathrm{eV}$, and $535.36 \mathrm{eV}$, attributing to $\mathrm{Fe}-\mathrm{O}, \mathrm{C}-\mathrm{O} / \mathrm{C}=\mathrm{O}$, and $\mathrm{O}-\mathrm{C}=\mathrm{O}$ in the immobilized lipase, respectively [31,32]. As compared to the magnetic support, the immobilized lipase had new N 1s XPS peaks located at $400.11 \mathrm{eV}$ and $399.19 \mathrm{eV}$, respectively, as shown in Figure 6f, which could be ascribed to $\mathrm{CO}-\mathrm{NH}-$ and amino groups of the lipase, evidencing the immobilization of the lipase on the magnetic support [32]. Overall, the above XPS results further validated that the $\mathrm{Fe}_{3} \mathrm{O}_{4}$ was indeed coated with the MIL-100(Fe) MOF and the lipase was loaded on the magnetic $\mathrm{Fe}_{3} \mathrm{O}_{4} @ \mathrm{MIL}-100(\mathrm{Fe})$ support.

The nitrogen adsorption-desorption isotherms of the $\mathrm{Fe}_{3} \mathrm{O}_{4} @ \mathrm{MIL}-100(\mathrm{Fe})$ and immobilized lipase microsphere are given in Figure 7. For the $\mathrm{Fe}_{3} \mathrm{O}_{4} @ \mathrm{MIL}-100(\mathrm{Fe})$ support, according to IUPAC (International Union of Pure and Applied Chemistry) classifications, the nitrogen adsorption-desorption isotherm exhibited mixed type I/IV curves with H2-type hysteresis loop, which was characteristic of both micro and mesopores [26]. However, the isotherm of the immobilized lipase was of type IV, indicative of the presence of mesoporosity. The $\mathrm{Fe}_{3} \mathrm{O}_{4} @ \mathrm{MIL}-100(\mathrm{Fe})$ had a high surface area of $271.1 \mathrm{~m}^{2} / \mathrm{g}$, a pore volume of $0.19 \mathrm{~cm}^{3} / \mathrm{g}$, and a mean pore size of $6.09 \mathrm{~nm}$. For the immobilized lipase sample, the surface area and pore volume were measured to be $36.43 \mathrm{~m}^{2} / \mathrm{g}$ and $0.12 \mathrm{~cm}^{3} / \mathrm{g}$, respectively, and the mean pore size was $6.88 \mathrm{~nm}$. Clearly, the decrease in the surface area and pore volume resulted from the binding of the Candida rugosa lipase. However, the mean pore size was shown to increase after the lipase immobilization. Such phenomenon has also been reported for MOF materials by other researches [23]. By drawing on the results, the high surface area and porous structure of the $\mathrm{Fe}_{3} \mathrm{O}_{4} @ \mathrm{MIL}-100(\mathrm{Fe})$ composites can endow the lipase to be highly dispersed on the magnetic support and then allow the efficient access of substrates to the bound lipase. 

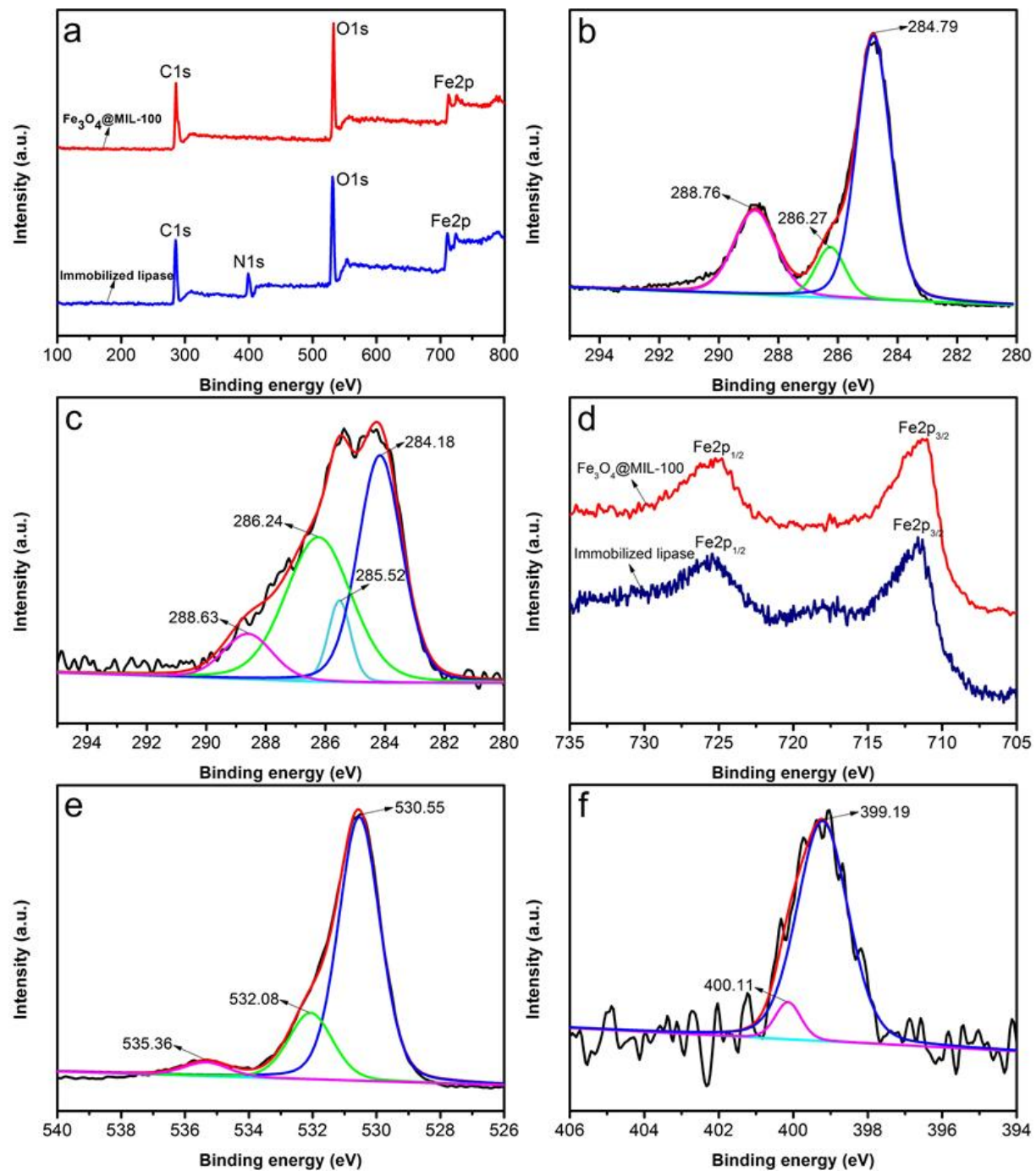

Figure 6. XPS spectra for (a) the survey spectra of $\mathrm{Fe}_{3} \mathrm{O}_{4} @ \mathrm{MIL}-100(\mathrm{Fe})$ and the immobilized lipase; (b) C 1s spectra of $\mathrm{Fe}_{3} \mathrm{O}_{4} @ \mathrm{MIL}-100(\mathrm{Fe})$; (c) C 1s spectra of the immobilized lipase; (d) Fe 2p spectra of $\mathrm{Fe}_{3} \mathrm{O}_{4} @ \mathrm{MIL}-100(\mathrm{Fe})$ and the immobilized lipase; (e) O 1s spectra of the immobilized lipase; and (f) N 1s spectra of the immobilized lipase.

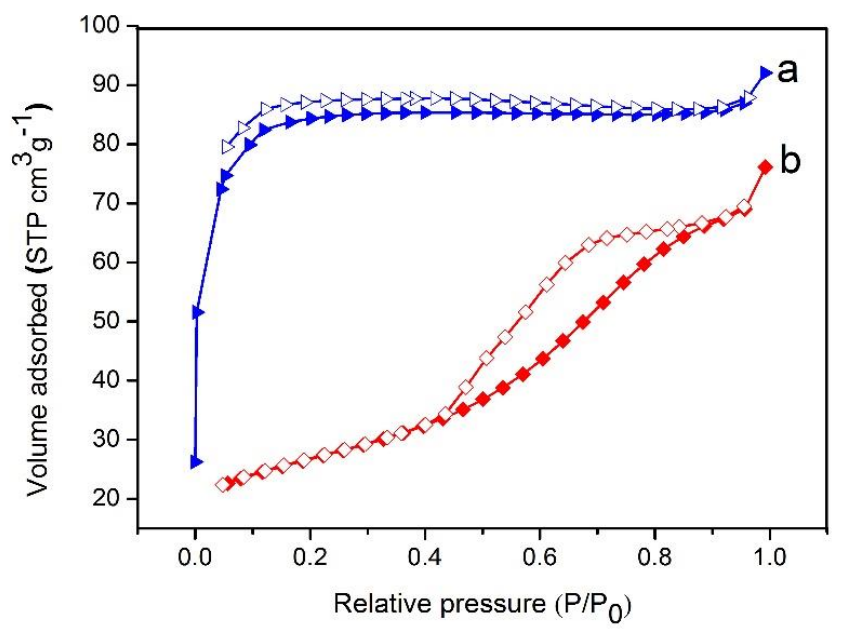

Figure 7. $\mathrm{N}_{2}$ adsorption-desorption isotherms of the $\mathrm{Fe}_{3} \mathrm{O}_{4} @ \mathrm{MIL}-100(\mathrm{Fe})$ support (a) and the immobilized lipase (b). 
The magnetic separability of the immobilized lipase was assessed using a vibrating sample magnetometer along with a visible magnetic separation experiment. The comparative magnetization hysteresis loops are illustrated in Figure 8. As could be seen, the magnetization curves of the three selected samples $\left(\mathrm{Fe}_{3} \mathrm{O}_{4}, \mathrm{Fe}_{3} \mathrm{O}_{4} @ \mathrm{MIL}-100(\mathrm{Fe})\right.$, and immobilized lipase) displayed almost zero coercivity or remanence at room temperature, and no hysteresis loop was clearly found, thereby indicating their paramagnetic properties $[16,18,32]$. Such magnetic features showed that the biocatalyst could be attracted by an external magnet, whereas no residual magnetism was retained as the magnetic field was removed. The corresponding saturation magnetization of the $\mathrm{Fe}_{3} \mathrm{O}_{4}$ magnetite was estimated to be $77.94 \mathrm{emu} / \mathrm{g}$. After coating of the MOFs, the saturation magnetization of the $\mathrm{Fe}_{3} \mathrm{O}_{4} @ \mathrm{MIL}-100(\mathrm{Fe})$ composite was decreased to $40.23 \mathrm{emu} / \mathrm{g}$. Probably, the decreased saturation magnetization value could be ascribed to the decrease in the $\mathrm{Fe}_{3} \mathrm{O}_{4}$ mass ratio in the magnetic support. For the immobilized lipase, the corresponding saturation magnetization was further decreased to $19.17 \mathrm{emu} / \mathrm{g}$. In spite of this, such saturation magnetization is sufficient for the magnetic biocatalyst to rapid migrate in an external magnetic field and also is suitable for easy magnetic separation. Hence, the immobilized lipase possesses a prompt response to a permanent magnet, which is very applicable for the efficient separation of the magnetic biocatalyst. As illustrated in the insert of Figure 8, the immobilized lipase could be quickly and completely separated from the liquid reaction mixture with minimal mass loss by using an external magnet. Moreover, it could be readily re-dispersed into the liquid reaction medium, with no evidence of agglomeration, by slight shaking after removal of the external magnet. Thus, the core-shell structured composite cannot only act as an enzyme support, but can also impart magnetism to the support for the convenience of separation and reuse.

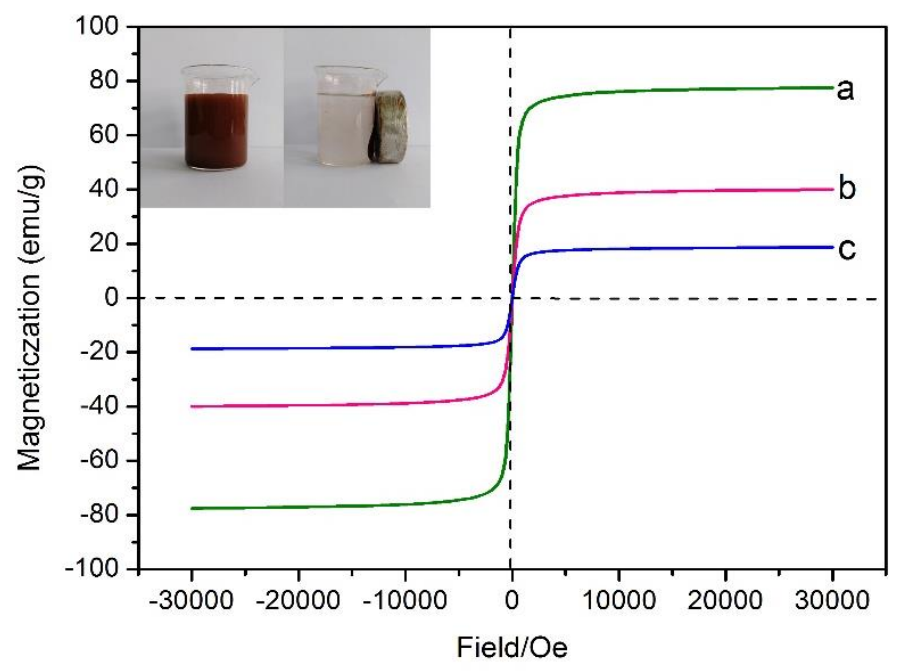

Figure 8. Room temperature magnetization curves for $\mathrm{Fe}_{3} \mathrm{O}_{4}$ microsphere (a), $\mathrm{Fe}_{3} \mathrm{O}_{4} @ \mathrm{MIL}-100(\mathrm{Fe})$ support (b) and the immobilized lipase (c).

\subsection{Factors Affecting the Immobilization Efficiency and Enzymatic Activity Recovery}

In order to ascertain the proper concentration of lipase for the immobilization process, different concentrations of lipase solution between 1.0 and $3.0 \mathrm{mg} / \mathrm{mL}$ were utilized for the binding of lipase on the $\mathrm{Fe}_{3} \mathrm{O}_{4} @ \mathrm{MIL}-100(\mathrm{Fe})$ support. As indicated in Figure 9a, the immobilization efficiency on the magnetic support was gradually decreased as the lipase concentration increased in the lipase concentration range investigated. However, for the activity recovery, an optimum lipase concentration of $2.0 \mathrm{mg} / \mathrm{mL}$ was observed, as shown in Figure 9a. In this case, the enzymatic activity recovery was shown to increase from $34.1 \%$ to $63.5 \%$ by enhancing the lipase concentration from $1.0 \mathrm{mg} / \mathrm{mL}$ to $2.0 \mathrm{mg} / \mathrm{mL}$; however, further increment in the lipase concentration beyond $2.0 \mathrm{mg} / \mathrm{mL}$ led to decreased activity recovery. A similar phenomenon has also been observed in several previous studies [12,33-35]. At a low lipase concentration, the low activity recovery was attained owing to less amounts of bound lipase. 
However, with lipase concentrations higher than $2.0 \mathrm{mg} / \mathrm{mL}$, the surface of the $\mathrm{Fe}_{3} \mathrm{O}_{4} @ \mathrm{MIL}-100(\mathrm{Fe})$ composite would be saturated, therefore causing steric hindrance among the enzyme molecules and thus blocking the catalytic sites on the bound lipase. From the above results, it is reasonable to suggest that the proper lipase concentration is $2.0 \mathrm{mg} / \mathrm{mL}$.
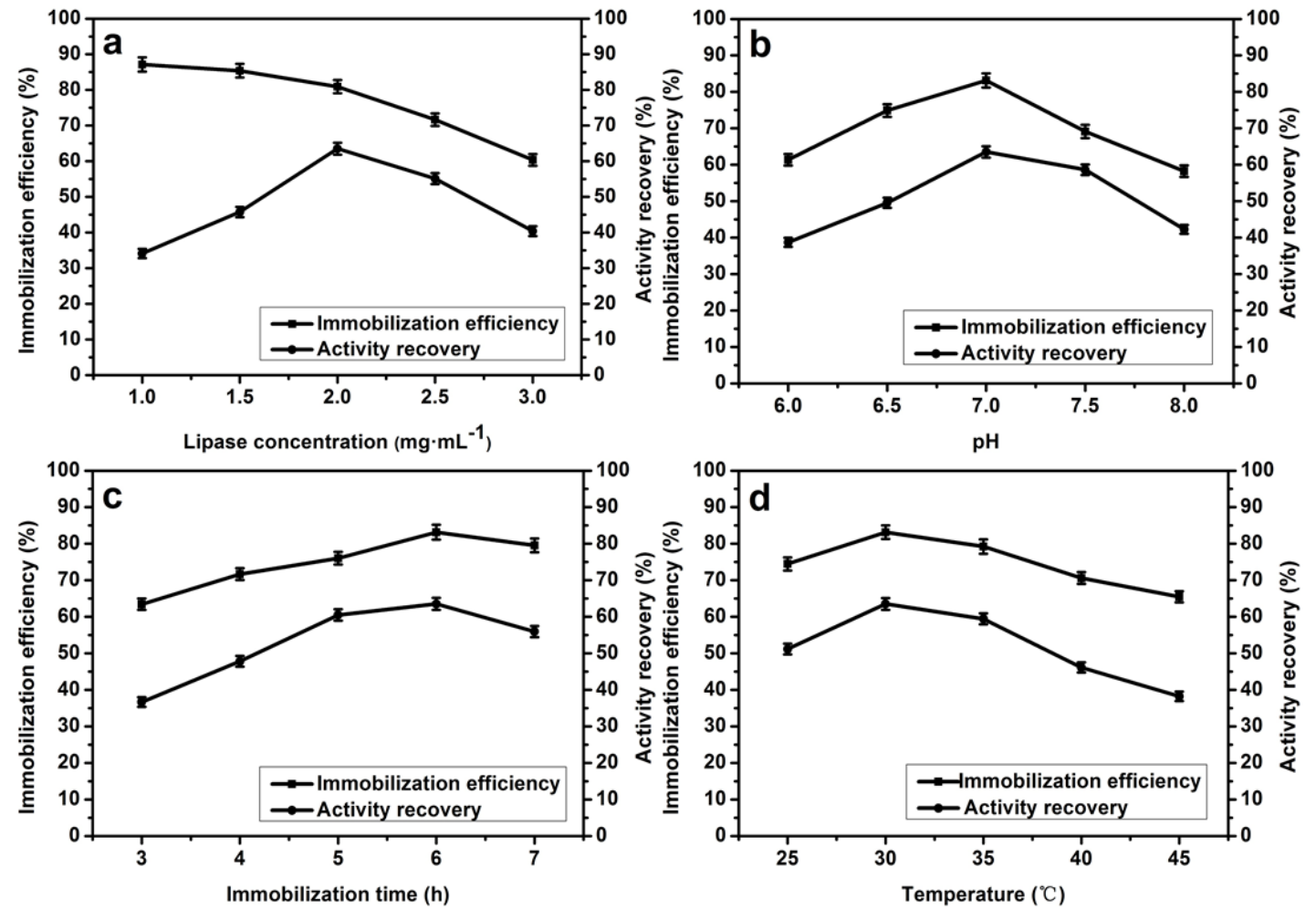

Figure 9. Influence of lipase concentration (a), $\mathrm{pH}(\mathbf{b})$, immobilization time (c), and immobilization temperature (d) on the immobilization efficiency and activity recovery. Other immobilization conditions, as follows: Immobilization temperature, $30{ }^{\circ} \mathrm{C}$; lipase concentration, $2 \mathrm{mg} \cdot \mathrm{mL}^{-1}$; $\mathrm{pH}$, 7.0; and immobilization time, $6 \mathrm{~h}$.

The immobilization efficiency and enzymatic activity recovery as a function of $\mathrm{pH}$ are given in Figure $9 \mathrm{~b}$. As can be seen, the two $\mathrm{pH}$ profiles showed similar patterns for the free and immobilized lipase, and the best immobilization efficiency and activity recovery were both achieved at the $\mathrm{pH}$ of 7.0. Moreover, the immobilization efficiency was increased from $61.4 \%$ to $83.1 \%$ by increasing the $\mathrm{pH}$ from 6.0 to 7.0 , and then started to decline as the $\mathrm{pH}$ rose higher than 7.0. In a similar trend, the activity recovery was improved from $38.2 \%$ to $63.5 \%$ with the $\mathrm{pH}$ increasing from 6.0 to 7.0 , reaching the highest level at the $\mathrm{pH}$ of 7.0, and then decreased upon further increment of the $\mathrm{pH}$ higher than 7.0. The $\mathrm{pH}$ has an influence on the ionic state of the enzyme and the polarity of the organic groups of the magnetic support. At pH 7.0, the lipase might be efficiently activated, which could increase the lipase binding onto the magnetic support. In light of the results, the $\mathrm{pH}$ of 7.0 was chosen for the lipase immobilization process.

The influence of immobilization duration on the immobilization efficiency and enzymatic activity recovery was studied at various immobilization times ranging from $3 \mathrm{~h}$ to $7 \mathrm{~h}$. As displayed in Figure $9 \mathrm{c}$, the immobilization efficiency was found to increase from $63.4 \%$ to $83.1 \%$ by prolonging the time from $3 \mathrm{~h}$ to $6 \mathrm{~h}$, and then declined slightly beyond $6 \mathrm{~h}$. Additionally, the enzymatic activity recovery tended to increase with the extension of the immobilization duration, and the highest activity recovery, $63.5 \%$, was obtained at the immobilization duration of $6 \mathrm{~h}$. Generally, a long immobilization duration can enhance the number of covalent bonds between the lipase and the magnetic support, thus increasing the activity recovery. However, the enzymatic activity recovery was decreased slightly 
as the immobilization duration further prolonged beyond $6 \mathrm{~h}$, which was most likely due to the lipase inactivation with a longer immobilization duration. By drawing on the results, the best immobilization time is considered to be $6 \mathrm{~h}$.

The immobilization efficiency and enzymatic activity recovery obtained for different temperatures are presented in Figure 9d. It could be seen that the highest immobilization efficiency and enzymatic activity recovery were both achieved at $30^{\circ} \mathrm{C}$. Increasing the temperature from $25^{\circ} \mathrm{C}$ to $30^{\circ} \mathrm{C}$ could lead to an increase in the immobilization efficiency from $74.4 \%$ to $83.1 \%$. Similarly, the enzymatic activity recovery was also improved with the increase in the temperature from $25^{\circ} \mathrm{C}$ to $30{ }^{\circ} \mathrm{C}$, since more lipase molecules were covalently bound onto the magnetic composites due to thermodynamic reason. However, as shown in Figure 9d, the increased temperature higher than $30{ }^{\circ} \mathrm{C}$ resulted in a decline in the immobilization efficiency and activity recovery. As a well-known phenomenon, the lipase could be thermally deactivated during the immobilization processes, and the activity is reduced when the temperature is lower or higher than the suitable temperature. Obviously, too much high temperature would cause protein denaturation and therefore decrease the enzymatic activity recovery. As such, the appropriate temperature for the lipase immobilization process is $30^{\circ} \mathrm{C}$. Overall, the suitable lipase immobilization conditions were as follows: A lipase concentration of $2.0 \mathrm{mg} / \mathrm{mL}$, an immobilization duration of $6 \mathrm{~h}$, and an immobilization temperature of $30^{\circ} \mathrm{C}$. In these conditions, the lipase loading amount on the $\mathrm{Fe}_{3} \mathrm{O}_{4} @ \mathrm{MIL}-100(\mathrm{Fe})$ composite was calculated to be $43.8 \mathrm{mg} / \mathrm{g}$ support.

The thermal stability of the immobilized lipase is a critical point for its practical applications. For the thermal stability test, the free and bound lipase were allowed to incubate at a temperature range of $30-80^{\circ} \mathrm{C}$ for $120 \mathrm{~min}$ in substrate-free phosphate buffer $(0.1 \mathrm{~mol} / \mathrm{L}, \mathrm{pH} 7.0)$. Thereafter, the residual hydrolytic activity was measured with olive oil as a substrate in the phosphate buffer $(0.1 \mathrm{~mol} / \mathrm{L}$, pH 7.0). As shown in Figure 10, the free and bound lipase exhibited a similar activity decrease trend. Comparatively, the free lipase showed a drastic decrease in the relative activity by enhancing the temperature. However, the residual activity for the immobilized lipase was decreased more slowly than the free lipase. The binding of lipase on the magnetic composite by the formation of covalent bonds provides a more rigid backbone of the lipase, thus protecting it from unfolding, preventing the denaturation of lipase at high temperatures, and thereby resulting in enhanced thermal stability. More specially, at a temperature of $60^{\circ} \mathrm{C}$, the free lipase remained only $51.2 \%$ of its original enzymatic activity, whereas the bound lipase remained $92.8 \%$ of its original enzymatic activity. Furthermore, the enzymatic activity of the free lipase was shown to decline rapidly above $50^{\circ} \mathrm{C}$, and the temperature range for the high enzymatic activity of the immobilized lipase was shown to be broader after the lipase immobilization. As the incubation temperature increased to $80^{\circ} \mathrm{C}$, the free lipase practically lost its initial enzymatic activity, whereas the immobilized lipase could keep $61.4 \%$ of its initial enzymatic activity. Hence, the immobilized lipase displayed a better thermal stability as compared to the free one.

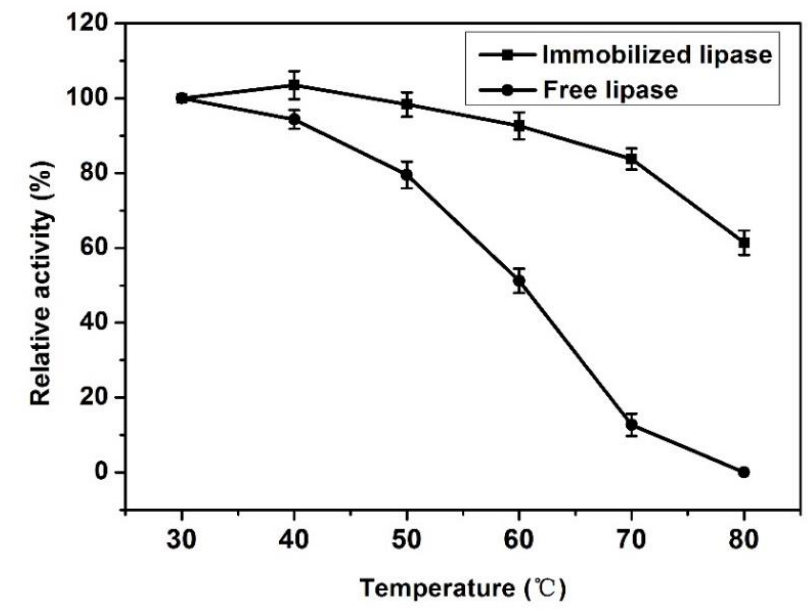

Figure 10. Thermal stability of free and immobilized lipase. 


\subsection{Immobilized Lipase-Catalyzed Transesterification Reaction of Soybean Oil}

From the stoichiometric ratio of the transesterification reaction, one mole of triglycerides requires three moles of methanol to produce three moles of fatty acid methyl esters (FAMEs). Generally, in order to shift the transesterification equilibrium to the biodiesel direction, an excess methanol is employed for biodiesel production. Unfortunately, the excess methanol suffers serious inhibitory effect on the enzymatic activity of lipase. As methanol has a low solubility in soybean oils, it easily forms droplets which coat the lipase, thus resulting in the deactivation of the lipase. In an attempt to reduce the detrimental effect of methanol, the stepwise methanol addition manner is frequently utilized in the lipase-catalyzed transesterification. By using this manner, methanol can be remained at a lower concentration in the reaction mixture [36]. Therefore, in this research, a three-step addition manner of methanol, by which the activity inhibition by methanol could be efficiently reduced, was adopted for the transesterification reaction. On the other hand, in most cases, the lids of lipase are always kept closed in the absence of an oil-water interface, thereby making the catalytic sites inaccessible to the substrates [11]. As such, the lipase catalyst usually demands a small amount of water to improve the lipase activity in the transesterification reaction in the nonaqueous media [11,14]. Therefore, in this work, $0.3 \mathrm{wt}$.\% of water (based on the oil mass) was initially introduced into the oil feedstocks for the magnetic biocatalyst to display its most active three-dimensional conformation in the reaction media.

The dependence of the soybean oil conversion to biodiesel on the methanol/oil ratio was explored using the three-step methanol addition procedure. As can be seen from Figure 11, the gradual increase in the oil conversion occurred as the methanol/oil molar ratio increased from 2:1 to 4:1, while keeping the other transesterification parameters unalterable. The maximum oil conversion of $92.3 \%$ was attained at the methanol/oil molar ratio of 4:1. By further enhancing the substrate molar ratio to 6:1, the conversion to biodiesel was decreased remarkably to $72.1 \%$. With low methanol loading, there was not enough reactant to be involved in the transesterification. However, higher methanol loading amount than methanol/oil molar ratio of 4:1 would increase the inhibitory effect of methanol on the lipase activity, thus decreasing the oil conversion. Based on the results, it can be inferred that the appropriate substrate molar ratio for this magnetic biocatalyst is 4:1.

The enzymatic transesterification of soybean oil was conducted by various amounts of this magnetic biocatalyst. Results presented in Figure 11 showed that the oil conversion was increased along with the enhancement of the biocatalyst amount to $25 \mathrm{wt} . \%$ (based on the oil mass), and then reduced slightly as the biocatalyst dosage was further increased to $30 \mathrm{wt} . \%$, probably owing to the increased mass transfer resistance in the three-phase (methanol-catalyst-oil) system. As a consequence, the proper amount of the biocatalyst chosen to perform the transesterification is $25 \mathrm{wt} . \%$.

Figure 11 shows the influence of reaction time on the oil conversion over the biocatalyst. At the initial $24 \mathrm{~h}$ of reaction, the conversion to biodiesel of $56.8 \%$ could be attained. Thereafter, the oil conversion was slowly increased with the progress of the transesterification to $60 \mathrm{~h}$, and further increase in the reaction time beyond $60 \mathrm{~h}$ did not result in the subsequent increment in the oil conversion. Obviously, after $24 \mathrm{~h}$ of reaction, the transesterification time had an insignificant influence on the oil conversion. The reason behind this phenomenon is not clear, and thus, further study is needed in the future. The maximum conversion of $92.3 \%$ was obtained at a reaction time of $60 \mathrm{~h}$. Accordingly, one can deduce that the favorable reaction time for the enzymatic transesterification reaction is $60 \mathrm{~h}$.

The influence of reaction temperature on enzymatic biodiesel production was also assessed. As seen from Figure 11, there was an increment in the oil conversion upon increasing the reaction temperature from $30{ }^{\circ} \mathrm{C}$ to $40{ }^{\circ} \mathrm{C}$. However, further increase in the transesterification temperature beyond $40^{\circ} \mathrm{C}$ had a reverse impact on the activity of the bound lipase, mostly owing to the reason of thermal deactivation, leading to decreased oil conversion. Therefore, it can be visualized that the proper reaction temperature for the enzymatic transesterification is $40^{\circ} \mathrm{C}$. 

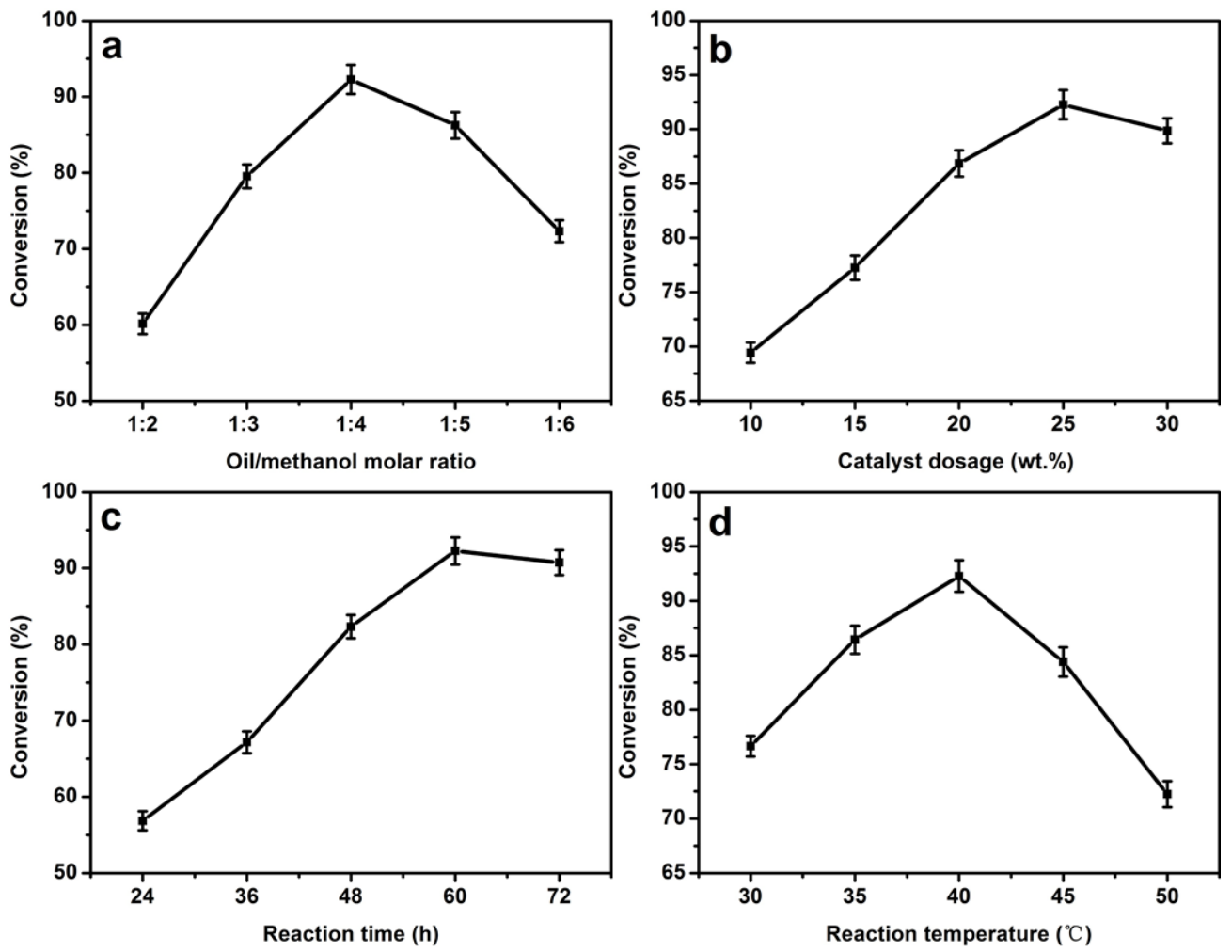

Figure 11. Influence of oil/methanol molar ratio (a), catalyst dosage (b), reaction time (c), and reaction temperature (d) on the oil conversion over the immobilized lipase. Other transesterification conditions are as follows: Biocatalyst amount, $25 \mathrm{wt} . \%$; methanol/oil molar ratio, 4:1; reaction temperature, $40{ }^{\circ} \mathrm{C}$; reaction time, $60 \mathrm{~h}$.

\subsection{Reusability of the Immobilized Lipase}

The reusability of the magnetic biocatalyst is one of the important factors, particularly in the viewpoint of industrial applications. To assess the reusability of the biocatalyst, the consecutive reactions were carried out under the optimized transesterification conditions. As the reaction had completed, the magnetic biocatalyst was removed from the reaction mixture with the aid of a permanent magnet, then washed with phosphate buffer solution $(0.1 \mathrm{~mol} / \mathrm{L}, \mathrm{pH} 7.0)$, and ultimately freeze-dried overnight. By the magnetic separation, there was no significant mass loss of the magnetic biocatalyst during the separation process. In the reusability test, the recovered biocatalyst was adopted for the next reaction cycle with fresh substrates, and the reuse results are presented in Figure 12. As can be observed, the enzymatic activity of the solid biocatalyst displayed insignificant loss after being reused for five cycles. Specifically, the residual lipase activity still retained about $84 \%$ of its initial lipase activity after the reuse for five cycles. The decline in the lipase activity could be originated from the denaturation of lipase during the transesterification processes. However, the covalent bonds between the enzyme and the magnetic support could lead to the stabilization of the configuration for the bound lipase and the improvement of its stability. Considering the reusability study, the long-term stability for the immobilized lipase is really comparable to that reported in the previous work $[19,23,33-35]$. 


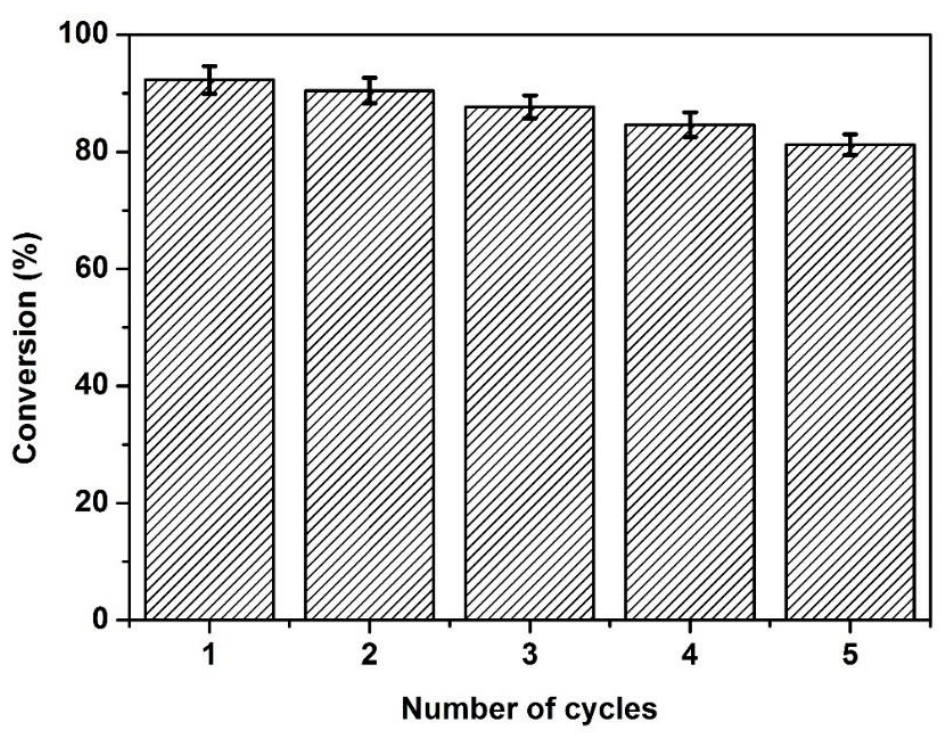

Figure 12. The reuse test results of the immobilized lipase for the transesterification of soybean oil. Reaction conditions as follows: Biocatalyst amount, $25 \mathrm{wt}$ \% ; reaction temperature, $40{ }^{\circ} \mathrm{C}$; methanol/oil molar ratio, 4:1; reaction time, $60 \mathrm{~h}$.

The leaching test was also performed in an attempt to verify the heterogeneous nature of the magnetic biocatalyst. For this purpose, the immobilized lipase was separated after $36 \mathrm{~h}$ of reaction (with $67.1 \%$ of the oil conversion), and the transesterification further proceeded with the liquid filtrate under the identical reaction conditions. It was shown that no further reaction progress occurred in the liquid filtrate without the immobilized lipase, signifying that the transesterification reaction was truly catalyzed by the bound lipase. Moreover, no enzyme was obviously detected in the biodiesel product by using the aforementioned Bradford method, which implied that the lipase was not leached during the biodiesel production.

Therefore, the immobilized lipase is a potential solid biocatalyst with high operational stabilities for biodiesel production. As taking the separation process into consideration, the magnetic biocatalyst shows better performance due to its convenient and efficient separation by applying an external magnetic field.

\section{Materials and Methods}

\subsection{Materials}

Commercial soybean oil, purchased from a local grocery store (Zhengzhou, China), presented the following fatty acid (FA) profiles: $49.4 \%$ linoleic acid, $26.5 \%$ oleic acid, $12.3 \%$ palmitic acid, $5.9 \%$ linolenic acid, 5.8\% stearic acid, and traces of other FAs. Commercial Candida rugosa lipase, N-hydroxysulfosuccinimide (NHS), bovine serum albumin (BSA), benzene-1,3,5-tricarboxylic acid ( $\mathrm{H}_{3} \mathrm{BTC}$ ), 1-ethyl-3-(3-dimethylaminopropyl) carbodiimide (EDC), and olive oil were procured from Sigma-Aldrich (St. Louis, MO, USA). Ethylenediaminetetraacetic acid disodium (EDTA-2Na), ferric chloride hexahydrate $\left(\mathrm{FeCl}_{3} \cdot 6 \mathrm{H}_{2} \mathrm{O}\right)$, ammonium acetate $\left(\mathrm{NH}_{4} \mathrm{OAc}\right)$, and ethylene glycol were of analytical grades.

\subsection{Preparation of Core-Shell Structured $\mathrm{Fe}_{3} \mathrm{O}_{4} @ M I L-100(\mathrm{Fe})$ Composites}

The carboxyl-functionalized $\mathrm{Fe}_{3} \mathrm{O}_{4}$ particles were initially prepared by means of a solvothermal method [37]. Typically, $\mathrm{FeCl}_{3} \cdot 6 \mathrm{H}_{2} \mathrm{O}(0.8 \mathrm{~g}), \mathrm{NH}_{4} \mathrm{OAc}(2.0 \mathrm{~g})$, and EDTA-2Na (0.5 g) were firstly dissolved in ethylene glycol $(50 \mathrm{~mL})$ and then stirred for $2 \mathrm{~h}$ at a temperature of $50{ }^{\circ} \mathrm{C}$. Thereafter, the resultant solution was transferred into a Teflon-lined stainless-steel autoclave, and was kept at $200{ }^{\circ} \mathrm{C}$ for $12 \mathrm{~h}$. After cooling down to ambient temperature, the formed magnetite precipitates were 
separated by magnetic separation, washed with anhydrous ethanol and deionized water, and finally dried under vacuum at $60^{\circ} \mathrm{C}$ for $24 \mathrm{~h}$.

The core-shell structured $\mathrm{Fe}_{3} \mathrm{O}_{4} @ \mathrm{MIL}-100(\mathrm{Fe})$ composites were prepared by a step-by-step self-assembly procedure with magnetite particles as cores [38,39]. Briefly, $0.1 \mathrm{~g}$ of the carboxyl-functionalized $\mathrm{Fe}_{3} \mathrm{O}_{4}$ particle was well-dispersed in an ethanol solution of $\mathrm{FeCl}_{3} \cdot 6 \mathrm{H}_{2} \mathrm{O}$ $(10 \mathrm{~mL}, 10 \mathrm{mM})$ under ultrasonication. After this, an $\mathrm{H}_{3}$ BTC ethanol solution $(10 \mathrm{~mL}, 10 \mathrm{mM})$ was added and subsequently permitted to stir at $70^{\circ} \mathrm{C}$ for $2 \mathrm{~h}$. The solid product was collected by applying an external magnet, and washed with anhydrous ethanol. The final $\mathrm{Fe}_{3} \mathrm{O}_{4} @ \mathrm{MIL}-100(\mathrm{Fe})$ composite was thus-obtained after 10 cycles of such runs by coating $\mathrm{Fe}_{3} \mathrm{O}_{4}$ cores with MIL-100 (Fe) and ultimately dried at $60^{\circ} \mathrm{C}$ overnight.

The $\mathrm{Fe}_{3} \mathrm{O}_{4} @ \mathrm{MIL}-100(\mathrm{Fe})$ composites exhibited a strong magnetic response to a permanent magnet and had carboxyl groups that could easily react with the enzyme to afford covalent bonds.

\subsection{Lipase Immobilization}

The lipase from Candida rugosa was immobilized on the $\mathrm{Fe}_{3} \mathrm{O}_{4} @ \mathrm{MIL}-100(\mathrm{Fe})$ composite according to the procedure described in Figure 1. Firstly, the $\mathrm{Fe}_{3} \mathrm{O}_{4} @ \mathrm{MIL}-100(\mathrm{Fe})$ composite $(0.1 \mathrm{~g})$ was dispersed in distilled water $(100 \mathrm{~mL})$ with ultrasound for $30 \mathrm{~min}$. After this treatment, $0.1 \mathrm{~g}$ of EDC and $0.08 \mathrm{~g}$ of NHS were added into the above solution and stirred for $2 \mathrm{~h}$ at ambient temperature, with the aim of activating the carboxyl groups of the magnetic support. Thereafter, the thus-activated magnetic support was collected by an external magnetic field and then washed thoroughly with distilled water. Meanwhile, a stock solution of lipase was prepared by dissolving a required amount of the Candida rugosa lipase in $100 \mathrm{~mL}$ of phosphate buffer solution $(0.1 \mathrm{~mol} / \mathrm{L}, \mathrm{pH}=7.0)$. Later, the activated magnetic $\mathrm{Fe}_{3} \mathrm{O}_{4} @ \mathrm{MIL}-100(\mathrm{Fe})$ support was added into the prepared lipase solution, and then the resultant solution was incubated at $30^{\circ} \mathrm{C}$ for $6 \mathrm{~h}$ in a shaking water bath with a continuous shaking rate $(120 \mathrm{rpm})$ so as to covalently bind the lipase. After magnetic separation, the immobilized lipase was washed with phosphate buffer solution $(0.1 \mathrm{~mol} / \mathrm{L}, \mathrm{pH}=7.0)$ in order to absolutely remove the unbound lipase, then freeze-dried overnight and, finally, stored at $4{ }^{\circ} \mathrm{C}$ prior to use.

At the same time, in this assay, the washing solutions were also collected for determining the amount of residual lipase. The lipase protein amounts in the original lipase solution and washing solutions were measured by the Bradford method, with BSA as a standard protein [40]. The loaded amount of lipase was assessed by subtracting the original amount of the protein from the residual protein in the washing solutions after the lipase immobilization. The lipase immobilization efficiency onto the magnetic support was calculated from the following equation:

$$
\mathrm{q}=\left(\mathrm{C}_{\mathrm{i}}-\mathrm{C}_{\mathrm{f}}\right) \mathrm{V}_{1} / \mathrm{C}_{\mathrm{i}} \mathrm{V}_{2}(\%)
$$

where $q$ represents the immobilization efficiency $(\%) ; C_{i}$ and $C_{f}$ are the concentrations of the initial soluble lipase, and the final lipase concentrations in the supernatant after the lipase immobilization, respectively $(\mathrm{mg} / \mathrm{mL})$; and $V_{1}$ and $V_{2}$ are the solution volume $(\mathrm{mL})$. All the determinations were carried out three times and the averages were presented with the standard deviations.

\subsection{Lipase Activity Assay}

The hydrolytic activity of the free and immobilized lipase was measured by using titrimetric assays based on an olive oil emulsion method [41]. The quantity of the hydrolyzed FAs was determined by the titration of the FAs derived from the hydrolysis of olive oil with a standard $\mathrm{NaOH}$ solution. One unit of enzymatic activity for the immobilized lipase was defined as the amount of enzyme that released $1 \mu \mathrm{mol}$ of FAs per minute under the assay conditions. The activity recovery (\%) was assessed as the ratio between the enzymatic activity of the bound lipase and the total activity of the lipase added in the initial solution. 
The thermal stabilities of the free and bound lipase were also investigated by determining the residual lipase activity after being incubated for $120 \mathrm{~min}$ at different temperatures in phosphate buffer solution $(0.1 \mathrm{~mol} / \mathrm{L}, \mathrm{pH}=7.0)$.

\subsection{Characterizations}

TEM photographs were acquired on a JSM-6390LV transmission electronic microscope operating at an accelerating voltage of $200 \mathrm{kV}$. XRD patterns were collected on a Rigaku D/max-3B X-ray diffractometer (Tokyo, Japan) using $\mathrm{Cu} \mathrm{K} \alpha$ radiation $(\gamma=0.1542 \mathrm{~nm}$ ) over the 2 theta ranges from $3^{\circ}$ to $80^{\circ}$. SEM micrographs were taken on a JEOL JSM-6390LV field-emission microscope. The $\mathrm{N}_{2}$ adsorption-desorption measurements were performed at $-196{ }^{\circ} \mathrm{C}$ using a Quantachrome NOVA 1000e instrument. The surface area was estimated by the Brunauer-Emmett-Teller (BET) method, while the pore size distribution and pore volume were assessed by the Barrett-Joyner-Halenda (BJH) method. XPS analyses were carried out with a Thermo ESCALAB 250XI spectrometer under ultrahigh vacuum. The $\mathrm{C}$ 1s peak $(284.6 \mathrm{eV})$ was used for the binding energy calibration. The FT-IR spectra were acquired with a Shimadzu IR-Prestige-21 spectrometer using the $\mathrm{KBr}$ pellet techniques. The magnetic susceptibility was measured by determining the magnetic hysteresis curve with a LakeShore model 7304 vibrating sample magnetometer (VSM) in the field range from $-30,000$ to $+30,000$ Oe.

\subsection{Enzymatic Transesterification Process}

The enzymatic transesterification of soybean oil was performed in a conical flask (100 mL) in a shaking incubator with a reciprocal shaker. In a typical experiment, the initial assay mixture contained $48.5 \mathrm{~g}$ of soybean oil and $25 \mathrm{wt} . \%$ (based on the initial oil mass) of the immobilized lipase. After the reaction temperature was raised to $40{ }^{\circ} \mathrm{C}, 5.4 \mathrm{~g}$ of methanol was introduced in a three-step addition manner. When the reaction was accomplished, the biocatalyst was magnetically separated from the liquid mixture, and then the excess methanol was removed absolutely under reduced pressure at $60^{\circ} \mathrm{C}$ using a rotary evaporator. After this, the obtained liquid reaction mixture was centrifuged at 6000 rpm for $20 \mathrm{~min}$. The upper phase containing FA methyl esters, un-reacted oil, mono and diglycerides, and the lower phase containing by-product glycerol were absolutely separated. The upper layer was assayed by using Agilent 7890A gas chromatograph fitted with a capillary column $(30 \mathrm{~m} \times 0.25 \mathrm{~mm}$ $\times 0.25 \mathrm{~mm}$ ) and a flame ionization detector. The soybean oil conversion to biodiesel was evaluated according to the GC analysis results by the method presented in the literature [42]. All experiments were conducted in triplicate, and the results are reported as the means with the standard deviations.

\section{Conclusions}

Core-shell structured $\mathrm{Fe}_{3} \mathrm{O}_{4} @$ MIL-100(Fe) composites were successfully prepared, and then Candida rugosa lipase was immobilized onto the magnetic hybrid composites through covalent amide bonds so as to obtain the magnetic biocatalyst. The immobilized lipase was employed for the transesterification of soybean oil to biodiesel in a solvent-free medium. The immobilized lipase not only showed catalytic activities to the transesterification reaction, but could also be reused several times with an insignificant loss of its activity. More importantly, as a technical advantage, the recovery of the solid biocatalyst was facilely accomplished using an external magnetic field, due to its strong magnetic responsiveness, which would have the potential for cleaner production of biodiesel.

Author Contributions: Conceptualisation, W.X. and M.H.; Formal analysis, W.X. and M.H.; Investigation, W.X. and M.H.; Methodology, M.H.; Supervision, W.X.; Writing—original draft, W.X.; Writing—review \& editing, W.X.

Funding: This research was funded by the National Natural Science Foundation of China (grant number 21776062) and the Key Scientific Projects of Universities in Henan Province of China (grant number 19zx002).

Conflicts of Interest: The authors declare no conflict of interest. 


\section{References}

1. Sharma, Y.C.; Singh, B.; Upadhyay, S.N. Advancements in development and characterization of biodiesel: A review. Fuel 2008, 87, 2355-2373. [CrossRef]

2. Aransiola, E.F.; Ojumu, T.V.; Oyekola, O.O.; Madzimbamuto, T.F.; Ikhuomoregbe, D.I.O. A review of current technology for biodiesel production: State of the art. Biomass Bioenergy 2014, 61, 276-297. [CrossRef]

3. Xie, W.; Wan, F. Immobilization of polyoxometalate-based sulfonated ionic liquids on UiO-66-2COOH metal-organic frameworks for biodiesel production via one-pot transesterification-esterification of acidic vegetable oils. Chem. Eng. J. 2019, 365, 40-50. [CrossRef]

4. Wang, A.; Li, H.; Pan, H.; Zhang, H.; Xu, F.; Yu, Z.; Yang, S. Efficient and green production of biodiesel catalyzed by recyclable biomass-derived magnetic acids. Fuel Process. Technol. 2018, 181, 259-267. [CrossRef]

5. Kouzu, M.; Fujimori, A.; Fukakusa, R.T.; Satomi, N.; Yahagi, S. Continuous production of biodiesel by the $\mathrm{CaO}$-catalyzed transesterification operated with continuously stirred tank reactor. Fuel Process. Technol. 2018, 181, 311-317. [CrossRef]

6. Xie, W.; Wang, H. Immobilized polymeric sulfonated ionic liquid on core-shell structured $\mathrm{Fe}_{3} \mathrm{O}_{4} / \mathrm{SiO}_{2}$ composites: A magnetically recyclable catalyst for simultaneous transesterification and esterifications of low-cost oils to biodiesel. Renew. Energy 2020, 145, 1709-1719. [CrossRef]

7. Christopher, L.P.; Kumar, H.; Zambare, V.P. Enzymatic biodiesel: Challenges and opportunities. Appl. Energy 2014, 119, 497-520. [CrossRef]

8. Aarthy, M.; Saravanan, P.; Gowthaman, M.K.; Rose, C.; Kamini, N.R. Enzymatic transesterification for production of biodiesel using yeast lipases: An overview. Chem. Eng. Res. Des. 2014, 92, 1591-1601. [CrossRef]

9. Amini, Z.; Ilham, Z.; Ong, H.C.; Mazaheri, H.; Chen, W.H. State of the art and prospective of lipase-catalyzed transesterification reaction for biodiesel production. Energy Convers. Manag. 2016, 141, 339-353. [CrossRef]

10. Xie, W.; Wang, J. Enzymatic production of biodiesel from soybean oil by using immobilized lipase on $\mathrm{Fe}_{3} \mathrm{O}_{4}$ /poly(styrene-methacrylic acid) magnetic microsphere as a biocatalyst. Energy Fuel 2014, 28, $2624-2631$. [CrossRef]

11. Garcia-Galan, C.; Berenguer-Murcia, Á.; Fernandez-Lafuente, R.; Rodrigues, R.C. Potential of different enzyme immobilization strategies to improve enzyme performance. Adv. Synth. Catal. 2011, 353, 2885-2904. [CrossRef]

12. Bonet-Ragel, K.; López-Pou, L.; Tutusaus, G.; Benaiges, M.D.; Valero, F. Rice husk ash as a potential carrier for the immobilization of lipases applied in the enzymatic production of biodiesel. Biocatal. Biotransfor. 2018, 36, 151-158. [CrossRef]

13. Arumugam, A.; Thulasidharan, D.; Jegadeesan, G.B. Process optimization of biodiesel production from Hevea brasiliensis oil using lipase immobilized on spherical silica aerogel. Renew. Energy 2008, 116, 755-761. [CrossRef]

14. Cipolatti, E.P.; Valério, A.; Henriques, R.O.; Moritz, D.E.; Ninow, J.L.; Manoel, E.A.; Freire, D.M.G.; Lafuente, R.F.; Oliveire, D. Nanomaterials for biocatalyst immobilization-state of the art and future trends. RSC Adv. 2016, 6, 104675-104692. [CrossRef]

15. Xie, W.; Zang, X. Lipase immobilized on ionic liquid-functionalized magnetic silica composites as a magnetic biocatalyst for production of trans-free plastic fats. Food Chem. 2018, 257, 15-22. [CrossRef] [PubMed]

16. Netto, C.G.C.M.; Toma, H.E.; Andrade, L.H. Superparamagnetic nanoparticles as versatile carriers and supporting materials for enzymes. J. Mol. Catal. B Enzym. 2013, 85-86, 71-92. [CrossRef]

17. Cunha, A.G.; Besteti, M.D.; Manoel, E.A.; da Silva, A.T.T.; Almeida, R.V.; Simas, A.B.C.; Fernandez-Lafuente, R.; Pinto, J.C.; Freire, D.M.G. Preparation of core-shell polymer supports to immobilize lipase B from Candida antarctica: Effect of the support nature on catalytic properties. J. Mol. Catal. B Enzym. 2014, 100, 59-67. [CrossRef]

18. Baharfar, R.; Mohajer, S. Synthesis and characterization of immobilized lipase on $\mathrm{Fe}_{3} \mathrm{O}_{4}$ nanoparticles as nano biocatalyst for the synthesis of benzothiazepine and spirobenzothiazine chroman derivatives. Catal. Lett. 2016, 146, 1729-1742. [CrossRef]

19. Miao, C.; Yang, L.; Wang, Z.; Luo, W.; Li, H.; Lv, P.; Yuan, Z. Lipase immobilization on amino-silane modified superparamagnetic $\mathrm{Fe}_{3} \mathrm{O}_{4}$ nanoparticles as biocatalyst for biodiesel production. Fuel 2018, 224, 774-782. [CrossRef] 
20. Xie, W.; Han, Y.; Wang, H. Magnetic $\mathrm{Fe}_{3} \mathrm{O}_{4} / \mathrm{MCM}-41$ composite-supported sodium silicate as heterogeneous catalysts for biodiesel production. Renew. Energy 2018, 125, 675-681. [CrossRef]

21. Chughtai, A.H.; Ahmad, N.; Younus, H.A.; Laypkov, A.; Verpoort, F. Metal-organic frameworks: Versatile heterogeneous catalysts for efficient catalytic organic transformations. Chem. Soc. Rev. 2015, 44, 6804-6849. [CrossRef] [PubMed]

22. Liu, W.L.; Yang, N.S.; Chen, Y.T.; Lirio, S.; Wu, C.Y.; Lin, C.H.; Huang, H.Y. Lipase-supported metal-organic framework bioreactor catalyzes warfarin synthesis. Chem. Eur. J. 2014, 21, 115-119. [CrossRef] [PubMed]

23. Xie, W.; Wan, F. Basic ionic liquid functionalized magnetically responsive $\mathrm{Fe}_{3} \mathrm{O}_{4} @ \mathrm{HKUST}-1$ composites used for biodiesel production. Fuel 2018, 220, 248-256. [CrossRef]

24. Wan, H.; Chen, C.; Wu, Z.W.; Que, Y.; Feng, Y.; Wang, W.; Wang, L.; Guan, G.F.; Liu, X. Encapsulation of heteropolyanion-based ionic liquid within the metal-organic framework MIL-100(Fe) for biodiesel production. ChemCatChem 2015, 7, 441-449. [CrossRef]

25. Zhang, F.M.; Jin, Y.; Shi, J.; Zhong, Y.J.; Zhu, W.D.; El-Shall, M.S. Polyoxometalates confined in the mesoporous cages of metal-organic framework MIL-100(Fe): Efficient heterogeneous catalysts for esterification and acetalization reactions. Chem. Eng. J. 2015, 269, 236-244. [CrossRef]

26. Abednatanzi, S.; Abbasi, A.; Masteri-Farahani, M. Immobilization of catalytically active polyoxotungstate into ionic liquid-modified MIL-100(Fe): A recyclable catalyst for selective oxidation of benzyl alcohol. Catal. Commun. 2017, 96, 6-10. [CrossRef]

27. Zhu, Y.T.; Ren, X.Y.; Liu, Y.M.; Wei, Y.; Qing, L.S.; Liao, X. Covalent immobilization of porcine pancreatic lipase on carboxyl-activated magnetic nanoparticles: Characterization and application for enzymatic inhibition assays. Mater. Sci. Eng. C 2014, 38, 278-285. [CrossRef]

28. Han, M.J.; Gu, Z.; Chen, C.; Wu, Z.W.; Que, Y.G.; Wang, Q.; Wan, H.; Guan, G.F. Efficient confinement of ionic liquids in the MIL-100(Fe) frameworks by the "impregnation-reaction-encapsulation" strategy for biodiesel production. RSC Adv. 2016, 6, 37110-37117. [CrossRef]

29. Xie, W.; Zang, X. Immobilized lipase on core-shell structured $\mathrm{Fe}_{3} \mathrm{O}_{4}-\mathrm{MCM}-41$ nanocomposites as a magnetically recyclable biocatalyst for interesterification of soybean oil and lard. Food Chem. 2016, 194, 1283-1292. [CrossRef]

30. Zhao, H.Y.; Qian, L.; Lv, H.L.; Wang, Y.B.; Zhao, G.H. Introduction of a $\mathrm{Fe}_{3} \mathrm{O}_{4}$ core enhances the photocatalytic activity of MIL-100(Fe) with tunable shell thickness in the presence of $\mathrm{H}_{2} \mathrm{O}_{2}$. ChemCatChem 2016, 7, 4148-4155. [CrossRef]

31. Xie, W.; Huang, Y. Immobilization of Candida rugosa lipase onto graphene oxide $\mathrm{Fe}_{3} \mathrm{O}_{4}$ nanocomposite: Characterization and application for biodiesel production. Energy Convers. Manag. 2018, 159, 42-53. [CrossRef]

32. Chen, Z.M.; Xu, W.H.; Jin, L.; Zha, J.J.; Tao, T.X.; Lin, Y.; Wang, Z.L. Synthesis of amine-functionalized $\mathrm{Fe}_{3} \mathrm{O}_{4} @ \mathrm{C}$ nanoparticles for lipase immobilization. J. Mater. Chem. A 2014, 2, 18339-18344. [CrossRef]

33. Liu, X.; Guan, Y.; Shen, R.; Liu, H. Immobilization of lipase onto micron-size magnetic beads. J. Chromatogr. $B$ 2005, 822, 91-97. [CrossRef] [PubMed]

34. Yang, X.; Chen, Y.; Yao, S.; Qian, J.; Guo, H.; Cai, X. Preparation of immobilized lipase on magnetic nanoparticles dialdehyde starch. Carbohydr. Polym. 2019, 218, 324-332. [CrossRef] [PubMed]

35. Sarno, M.; Luliano, M. Highly active and stable $\mathrm{Fe}_{3} \mathrm{O}_{4} / \mathrm{Au}$ nanoparticles supporting lipase catalyst for biodiesel production from waste tomato. Appl. Surf. Sci. 2019, 474, 135-146. [CrossRef]

36. Ranganathan, S.V.; Narasimhan, S.L.; Muthukumar, K. An overview of enzymatic production of biodiesel. Bioresource Technol. 2008, 99, 3975-3981. [CrossRef]

37. Wang, J.Z.; Zhao, G.H.; Li, Y.F.; Peng, X.M.; Wang, X.Y. Preparation of amine-functionalized mesoporous magnetic colloidal nanocrystal clusters for glucoamylase immobilization. Chem. Eng. J. 2015, 263, 471-478. [CrossRef]

38. Bradford, M.M. A rapid and sensitive method for the quantitation of microgram quantities of protein utilizing the principle of protein-dye binding. Anal. Biochem. 1976, 72, 248-254. [CrossRef]

39. Shao, Y.; Zhou, L.; Bao, C.; Ma, J.; Liu, M.; Wang, F. Magnetic responsive metal-organic frameworks nanosphere with core-shell structure for highly efficient removal of methylene blue. Chem. Eng. J. 2016, 283, 1127-1136. [CrossRef] 
40. Tsuruoka, T.; Kawasaki, H.; Nawafune, H.; Akamatsu, K. Controlled self-assembly of metal-organic frameworks on metal nanoparticles for efficient synthesis of hybrid nanostructures. ACS Appl. Mater. Inter. 2011, 3, 3788-3791. [CrossRef]

41. Abramić, M.; Leščić, I.; Korica, T.; Vitale, L.; Saenger, W.; Pigac, J. Purification and properties of extracellular lipase from Streptomyces rimosus. Enzym. Microb. Tech. 1999, 25, 522-529. [CrossRef]

42. Standards, B. Fat and Oil Derivatives-Fatty Acid Methyl Esters (FAME)-Determination of Ester and Linolenic Acid Methyl Ester Contents; Standards Policy and Strategy Committee, British Standards Institute: London, UK, 2003.

(C) 2019 by the authors. Licensee MDPI, Basel, Switzerland. This article is an open access article distributed under the terms and conditions of the Creative Commons Attribution (CC BY) license (http://creativecommons.org/licenses/by/4.0/). 